\title{
Participatory and incremental development in an African local government accounting reform
}

\begin{abstract}
Despite significant donor funding, government accounting reforms seeking transparent and effective management of public resources often fail or have limited success, especially in Africa, prompting questions about donors' implementation approach and calls for studies of successful reforms. This paper investigates a local government accounting reform in Benin supported by a German development agency - perceived as successful due to the participatory, pragmatic and incremental approach reinforced by conditionalities in the face of neopatrimonial leadership.
\end{abstract}

Key words: Accounting, local governance, Benin, poverty reduction, development agencies 


\section{Participatory and incremental development in an African local government accounting reform}

\section{Introduction}

Government accounting reforms in Africa to fight corruption and mismanagement, and improve transparency and accountability have disappointed (Andrews, 2012, 2013; Harrison, 2004; Hopper et al., 2012, 2016). They generally emanate from the World Bank (WB), the International Monetary Fund (IMF), and bilateral development arrangements agencies from developed countries, who often contract out the design and implementation to consultants from 'Northern', often 'Big 4', accounting firms (Graham and Annisette, 2012). Research (Iyoha and Oyerinde, 2010; Goddard et al., 2015; Lassou and Hopper, 2016) and donor reports (Hove and Wynne, 2010; Lienert and Sarraf, 2001) suggest indigenous civil servants are often marginalised (Schiavo-Campo, 2009), perceived negatively and as 'passive recipients' of Northern technologies (Neu et al., 2006) likely to resist due to self-interest (Bierschenk et al., 2003). In parallel, foreign consultants neglect gradual, incremental change, and import overly complex systems unsuited to local circumstances (Andrews, 2013; Hove and Wynne, 2010; McLeod and Harun, 2014). Hence calls for studies of successful accounting reforms, especially decentralised donor-led developments within communities, villages and social groups, to determine what produces better outcomes (Rondinelli and Nellis, 1986).

Research examining greater indigenous involvement is sparse, especially on local government where good governance initiatives foster decentralised, grassroots budget participation (Fontana and Grugel, 2016; WB, 1997, 2003). Hence, this paper analyses how civil servants in Benin, with support from $\mathrm{GIZ}^{1}$ (a German development agency), successfully designed and implemented a local government accounting reform (WMONEY) under difficult circumstances, especially neo-patrimonial governance. It contributes to research on participatory development of government accounting in developing countries (Lassou and Hopper, 2016). Section 2 presents the research arguments and analytical framework; Section 3 the research methods; Section 4 the reform's context; Section 5 the findings; and Section 6 the conclusions.

\section{Accounting reform in Africa: reconciling participatory development with neo- patrimonialism}

Development policies in Africa have veered from state socialism to neo-liberalism, and currently around good governance (Hopper et al. 2017). A recurring finding is that (regardless of approach), when sound accounting and accountability systems are adopted, they often play a ceremonial role to gain legitimacy from citizens and external funders rather than aiding ministerial and parliamentary scrutiny, operational decision-making and accountability (Hopper et al., 2009). Political not legal-rational or economic criteria dominate when politicians exercise patronage to bolster political support or for personal gain. The result is often fiscal crises and requests for

\footnotetext{
${ }^{1}$ Gesellschaft für Internationale Zusammenarbeit (GIZ), established by the German Federal Ministry for Economic Cooperation and Development, is one of two German development agencies. It seeks international cooperation for sustainable development in over 130 countries (including 39 African countries). In Benin, GIZ is involved in proverty reduction and capacity buiding at central and local government levels. It focuses on: decentralisation and municipal development (good governance); agriculture and adaptation to climate change; and rural/urban water supply and sanitation and its management..In 2015, GIZ's activities worldwide was estimated at over 2.1 billion euros (see. https://www.giz.de/en/html/index.html [Accessed: 27/03/2017]
} 
assistance from international financial institutions, especially the IMF and the WB, who in the 1980s and 1990s, regarded many governments as too big, unwieldy, corrupt, and a hindrance to development. Conditions for assistance, often in structural adjustment programmes, reflected a neo-liberal, market-based agenda. New Public Management, incorporating private sector-based accounting and, from the late 1990s, integrated financial management information systems and medium-term expenditure frameworks were frequently prescribed. Aware that fiscal crises precipitate political crises, African governments knew they must (or appear to) comply. IMF and WB officers, until recently predominately macroeconomists, saw accounting as a technical matter and usually followed advice from Northern accounting professional bodies, transnational accounting bodies (e.g. International Federation of Accountants), and 'Big 4' accounting firms (Hopper et al., 2009; 2012). They tended to recommend 'one-size fits all' packages (Hedger and de Renzio, 2010) incorporating 'best practices' from developed countries, albeit with terminological changes to insinuate local adaptation (Awio et al., 2007; Hove and Wynne, 2010; Schiavo-Campo, 2009). The results often disappointed (Andrews, 2012). Many reforms lacked contextual fit, outstripped local capacity, demoralised civil servants, lacked political support and were overly complex and 'ill-conceived' (Bakre, 2008; Andrews, 2013); leading to allegations that the WB is obsessed with large development programmes and evaluating a country's accounting progress by its adoption of international standards and systems (Harrison, 2004).

Recently, emphasis has switched to the 'Capable State' and 'Good Governance' (WB, 1992, 1997). Market-based reforms remain but alongside building capacity in state institutions, increasing business and civil society involvement, and transparent information. Many countries undertook such reforms voluntarily although they were often conditions for financial assistance (Chang, 2006). More donor funding now enters government coffers directly rather than to specific projects and delivery agencies. This requires better accounting controls; better motivated, trained and remunerated civil servants; and greater delegation of powers and resources to local governments and communities, e.g. through village development committees, commune accountability boards, and citizen complaint procedures.

'Participatory development', whilst not novel (Cleaver, 1999; Morris, 2003), has moved up the discursive agenda of international development institutions (Ackerman, 2004; WB, 1997, 2003), which tallies with researchers' calls for more indigenous involvement in government accounting reforms (Schiavo-Campo, 2009). This does not preclude learning from developed countries but uses local knowledge to incorporate citizen priorities into local decisions and to improve accountability (Bland, 2011). However, different 'shades' and models of participatory development exist. Who is 'invited', how they participate, and when 'local' participation arises, underpin the motives for, and outcomes of, participation. For instance, reasons may be efficiency, i.e., help developers achieve project outcomes within means, or empowerment, i.e. improve participants' capacity to improve their lives and/or grant disadvantaged or marginalised social groups greater voice (Cleaver, 1999). An efficiency-led approach is instrumental. It grants local actors limited agency and expects them to operate apolitically (Cleaver, 1999) whereas in a participative approach people are seen "as agents rather than objects; capable of analyzing their own situations and designing their own solutions" (Cornwall and Jewkes, 1995: 1670). Participatory techniques often can legitimise projects rather than seek real change (Ackerman, 2004; Harrison, 2004; Speer, 2012; Irvin and Stansbury, 2004) yet they have had successes in accounting, e.g., decentralised budgeting, and community-based accountability combined with some new public management-style reporting 
in Uganda (Awio and Northcott, 2001; Awio et al., 2007); and Ghanaian state agencies' involvement in designing performance contracts (Dodoo, 1997). Accounting reforms can progress, especially if initially small-scale and they expand carefully and incrementally, recognising the process's long-term nature (Rondinelli and Nellis, 1986; Romijn and Caniels, 2011).

Weak governance, especially neo-patrimonialism ${ }^{2}$, frustrate many African initiatives (Cammack, 2007; Médard, 1983). Neo-patrimonialism exists when political control rests on personal and/or charismatic power. A Weberian rational-legal bureaucracy and a formal façade of rules may exist but political leaders override or ignore them and raid public resources for private use, political gain or to maintain patronage, clientelism, corruption, nepotism, or ethnic/religious primacy (Hopper, 2017). Opaque management (or mismanagement) of state resources and weak accounting often go hand-in-hand with this, leading to misappropriations of state funds and jobs, and non-payment of taxes (Akakpo, 2009). Tacit acceptance fosters civil service incompetence and mediocracy, and hinders capacity building (Sandbrook and Oelbaum, 1997). Neo-patrimonial leaders may not welcome transparent accounting that improves accountability but may adopt it for legitimacy and external funding purposes and then ignore or circumvent it or even use it to persecute political opponents (Harrison, 2004).

Whilst the neopatrimonialism concept has been criticised (especially by development economists e.g. Moreno, 2003; Mkandawire, 2015), it permeates many African government accounting reforms (Hopper et al., 2009; Hopper, 2017). Neopatrimonialism may not be invariably problematic from an economic perspective - centralised pro-development neo-patrimonial leadership can provide essential vertical authority, coordination and support for development projects combined with local problem solving attuned to local cultures (Crook and Booth, 2011; Hopper, 2017); and they can make effective bureaucratic reforms (von Soest, 2006). Moreover, depicting all relations as privatized or informal does not reflect African realities one must distinguish between rulers and officials. For example, following donor advice and despite a neo-patrimonial regime, Zambia's Revenue Authority was established resulting in less corruption, an effective tax collection bureaucracy, and increased tax revenues (von Soest, 2006); and civil servants granted substantial autonomy and clear lines of responsibility in Ghana and Tanzania reformed corrupt and inefficient departments (Fjeldstad, 2003; Olowu, 1999).

This research explores these issues by investigating whether a decentralised local government accounting reform in Benin by indigenous officials was more effective than all-encompassing systems designed and implemented by foreign experts at the national level at a foreign government's behest. It reveals how central government officials and GIZ helped enact politically feasible reforms in the face of neo-patrimonial leadership.

\section{Research methods}

During a project examining government accounting in Francophone Africa, Treasury and Accounting Department (TAD) officials in Benin mentioned a computerised accounting system, WMONEY, designed locally to produce local government accounts. It was decided to investigate this as research on local government accounting reforms in Africa is sparse, especially successful ones that produce financial accounts and information for decision-making,

\footnotetext{
${ }^{2}$ For detailed theoretical development, see Lassou and Hopper (2016)
} 
make resources transferred to municipalities and their expenditure more transparent; and increase citizen and local community involvement in budgeting and accountability.

A letter and interview guide was submitted to the TAD but data collection was delayed. Public administration in Francophone Africa is characterised by secrecy, and access to information is difficult and challenging (Verschave and Bakaria, 2001; Lassou and Hopper, 2016). This persisted throughout field visits in August and November 2014, and December 2015. Despite formal authorisation, it proved impossible to interview several officials. Typically, some would accept invitations but repeatedly find excuses to postpone interviews or vacated their office at the scheduled time, which enabled them to decline without appearing to say so.

Eventually ten participants ${ }^{3}$ participated: four TAD officials who developed and used WMONEY; three public accountants in three local governments who used WMONEY; a local government budgetary accountant; and two GIZ officials who helped coordinate and advise on the project. Semi-structured interviews with open-ended questions were conducted. Responses were corroborated to increase the validity and reliability of findings. Four interviews were faceto-face, four by telephone and two by Skype. Three interviewees were re-interviewed to confirm responses and get additional data. Interviews lasted between thirty minutes and one hour forty minutes. Notes were taken and interviews recorded electronically, where feasible or permitted.

Some attempts to access relevant documents were successful - others were not. For example, the State Chief Accountant - the Receveur Général des Finances - recommended getting these from the Division responsible for documentation but when approached, they denied access without his authorisation. From then further contact was impossible. Nonetheless, documents on the accounting reforms' results and WMONEY's functionalities, a user manual, and an assessment report, from other sources and GIZ were helpful. Further corroborating evidence came from workplace observations. The data was coded manually regarding participatory and incremental development, neo-patrimonialism, actors involved, incentives provided, roles played, activities performed, and outcomes achieved.

\section{Benin and the context of accounting reforms}

Benin is a low-income economy; its population of 10.9 million in 2015 has a gross national income per capita of US\$762 ${ }^{4}$. Life expectancy is 54 and 58 for males and females respectively; adult literacy is $42 \%$ (WB, 2013); and it ranks $165^{\text {th }}$ of 187 countries on the 2014 human development index. Formerly a French colony from 1902-1960, it gained independence in 1960 and was politically stable until 1963. Various coups d'état occurred until 1972 when an authoritarian Marxist-Leninist military regime assumed power. It collapsed in 1989 amidst widespread financial and macroeconomic mismanagement and endemic corruption (Akapko, 2009; Gisselquist, 2008). Benin virtually had no accounting institutions at independence. The TAD and Chambre des Comptes - the supreme audit institution - were created but their functionality was limited. Following a transition period (1989-1991), under international pressure, Benin adopted a new Constitution incorporating a democratic multi-party political system. Presidential and parliamentary elections have occurred every five years and four years respectively, with some media and civil society scrutiny. However, no government accounts materialised until 1998. Accounting was manual, dominated by budgetary allocations and cash disbursements, and weak recording and controls, mostly at TAD headquarters, facilitated errors, collusion and fraud.

\footnotetext{
${ }^{3}$ Respondents' exact profile is not disclosed to retain confidentiality.

${ }^{4}$ http://www.worldbank.org/en/country/benin [Accessed: 27/03/2017]
} 
Despite its pluralist democracy and the rule of law remaining incomplete, Benin is cited as a 'model' of democracy, given the region's weak democratic credentials (Bierschenk and de Sardan, 2003). Benin has implemented several poverty reduction strategy policies within structural adjustment programmes requiring improvements in its macroeconomic environment, health and education, public financial management, and good governance (IMF, 2003). Implementation relies on foreign expertise and finance, and donor pressure (Bierschenk et al., 2003; African Development Bank, 2012; WB, 2011). The political system favours the executive, particularly the President, who can bypass the Assemblée Nationale (Parliament) and the budgetary process (African Development Bank, 2005). Benin's governance remains neo-patrimonial: characterised by clientelism, politicised administration, corruption, and weak state regulatory and implementation capacities. This frustrates accounting reforms within poverty reduction initiatives (Bierschenk et al., 2003), and circumvents internal controls introduced to reduce embezzlement (Blundo et al., 2006).

In 1998-1999, a central government accounting system (WMONEY), designed by indigenous IT civil servants, was implemented but was replaced by a French system (ASTER) around 2002-2004. Both systems are computerised accounting programmes that record government transactions and produce financial reports. Germany, a major donor, supported the first local elections in 2002, which brought about seventy-seven municipalities. They wanted to: increase grassroots participation in identifying development needs and allocating municipal resources; and improve accountability and delivery of services (Bierschenk and de Sardan, 2003). GIZ has operated in Benin for thirty-five years supporting sustainable development and poverty reduction initiatives ${ }^{5}$. In 2012, it approached the TAD offering to improve local government accounting. It realised weak accounting and accountability, and limited transparency had stymied development programmes. After discussions with TAD officials and IT staff, they agreed to adapt WMONEY for this purpose.

\section{Participatory and Incremental Development}

\subsection{Context of local government accounting reforms}

No legal local government framework existed until 1999 despite Articles 150-153 in the Constitution stipulating that elected local government members, led by an elected Mayor, have financial autonomy. After the 2002 elections, local governments' financial management capacity was weak and under-resourced. It was impossible to get information on financial resources from donors and central government or how they were managed, which facilitated mismanagement and corruption. Donors had concentrated on central government accounting with scant attention to that of local governments. This changed in 2012 when twenty-five of the seventy-seven local governments received direct support from GIZ for accounting reforms.

Receveurs-Percepteurs (public local government accountants) should send annual financial accounts (Compte de Gestion) for each local government to the Chamber of Accounts (Chambre des Comptes). However, TAD officials claimed the law did not prescribe how and in what form, so they were not produced. A GIZ official observed:

The accounting function performed by the local public accountants before... WMONEY ...was a major problem ...they were not equipped .... and others had little knowledge about what they were expected to do.

Hence GIZ's desire for reforms, as a GIZ official explained:

\footnotetext{
${ }^{5}$ See: https://www.giz.de/en/worldwide/342.html [Accessed 8/12/2015]
} 
To support not only the budget side but also ...the spending side to ensure some transparency ... and improve information flows on the use of local governments' budget ... [and] between local and central governments, and facilitate transparency of FADEC transfers ${ }^{6}$.

Initially, GIZ were unaware of WMONEY. A GIZ official explained:

One option was to impose a financial system from elsewhere ...but often these are not transferable and ...there may be licence costs. ... There may be locally available solutions ... Since we are not IT or accounting experts, we ... seek solutions that can work .... in consultation with the partner country. ... The other consideration is promotion of local expertise.

Consistent with their participatory approach, GIZ discussed this with the TAD, who told them about WMONEY. A local development officer recalled:

GIZ was looking for an accounting programme ...they had problems with accountability and the production of the Compte de Gestion in local governments and needed a solution... We told them we don't need their financial resources to provide our Recettes-Perceptions ${ }^{7}$ with an accounting programme - we've got what they need [i.e., WMONEY]. They said OK, 'you have six months to prove yourselves'.... Within six months we started producing results.

The GIZ official confirmed this noting lessons from earlier budgeting reforms:

Developers [private firms] had a monopoly position ...[local] options could be less costly and the source codes would be under the control of the Ministry of Finance. So, for WMONEY we wanted the TAD to take control ...they had already worked on it.

Despite WMONEY's abandonment for central government accounting, TAD's IT staff had repeatedly requested permission to redesign it for local government accounting. This tallied with GIZ's belief that local accounting solutions by local officials are more effective and cheaper than imported programmes implemented by foreign consultants.

A TAD development team began redesigning WMONEY in 2012. Users, i.e. local government public accountants, provided accounting expertise and helped tailor WMONEY to their needs and working environment.

We [IT staff] started working on the project ...with those in charge of local government accounting (Service des Collectivités Locales) at the TAD. ...We also had the ReceveursPercepteurs who provided information about the state of things and what they needed. That was the preparation phase. [Development team member].

The development team had experienced TAD IT staff - computer science graduates from the state's school of management and economics (Institut National d'Economie). ${ }^{8}$ They had undertaken training on government accounting by the regional oversight body - UEMOA ${ }^{9}-$ and donors, mostly the WB, IMF and the European Union (EU). They undertook regular personal development using the internet, IT resources, and manuals. Most senior public accountants graduated from the state's school of public administration (Ecole Nationale d'Administration). ${ }^{10}$ Many had undertaken postgraduate studies in public administration at France's Ecole Nationale du Trésor. However, local government accountants - the ReceveursPercepteurs - only graduated from the Ecole Nationale d'Administration; some lacked a

\footnotetext{
${ }^{6}$ FADEC is the Municipal Development Support Fund (Fonds d'Appui au Développement Communal) whereby ministries and donors transfer resources to local governments.

${ }^{7}$ TAD decentralised offices responsible for local governments' accounting.

${ }^{8}$ Now: Ecole Nationale d'Economie Appliquée et de Management (ENEAM)

${ }^{9}$ Union Economique et Monétaire Ouest Africaine or 'West African Economic and Monetary Union' covering

Benin, Burkina Faso, Cote d'Ivoire, Guinea-Bissau, Mali, Niger, Senegal, and Togo.

${ }^{10}$ Now: Ecole Nationale d'Administration et de Magistrature.
} 
degree after the Baccalaureate (i.e., A-Level equivalent). They needed several years of experience before being appointed but not invariably so.

Initially TAD officials believed their staff responsible for local governments had sufficient expertise but development team members realised user involvement was crucial after meeting local government accountants:

We worked with internal people but sometimes they did not have much on-site experience and didn't know much of the realities on the ground... [So] the information gathered at the TAD headquarters was not really adapted ... we only learnt this during the first training to selected actual users [Receveurs-Percepteurs]. Fortunately, this allowed us to make necessary corrections.

We realised there were many aspects we developed which were not relevant to their reality because we did the design with people [at the headquarters] who were rather theoretical with limited practical considerations.

So the development team involved users, with TAD personnel supplying leadership, coordination and IT expertise. The programme was implemented incrementally. A pilot was launched at one local government to assess its effectiveness and to limit failure costs should it fail. The results convinced doubters. A GIZ official recalled:

The pilot phase focused on the redesign of WMONEY's functionalities. Once this was completed ....we used a local government - Ouidah - to test the programme. ...A team entered all the accounting data covering the whole financial year into WMONEY and conducted the related accounting treatments. Following this, the year-end accounts were produced successfully. We presented these results to those who were reluctant to show them that with WMONEY they would do things more quickly, ... and they would produce accounts ...more reliable than when they had used Excel.

GIZ organised training sessions and workshops for users and local government officials to build capacity 'and to institutionalise WMONEY so people use it' [GIZ official]. They covered technical aspects of WMONEY but also computer literacy because, 'some Receveurs [had] never used a computer [senior TAD official]. Indeed, 'some public officials holding accounting positions were not well qualified to use the tools they were provided with-not all could work with a computer' [GIZ official].

Sustaining accounting reforms is challenging in Africa. Many fail and disappear once donor support ends or locals lack the resources and capacity to sustain them (Andrews, 2013; Hopper et al., 2012). GIZ recognised this and ran training repeatedly, partly to address staff transfer problems. A GIZ official reflected:

Unfortunately, staff transfers do not recognise the efforts made by donors and the TAD ...We run training sessions for them and soon after they are moved ...It is a major challenge... that's why we run the training again and again for users ...most who undertook the training in 2013 are no longer in position.

WMONEY was formally adopted and extended, with GIZ support, to twenty-four TAD decentralised offices dealing with local governments' accounting. A development team member observed how:

Upon this decision ...we wanted the first results to show at the year-end. We were on-site in local governments and working hard to assist the accountants ...to enter all transactions ...from the start of the year - it wasn't easy... We managed to do it for all 25 local governments.

By 2013 WMONEY was effective. A GIZ 2014 presentation reported: 
WMONEY is the accounting programme in local governments ...used by local public accountants to produce the decadal, monthly and annual situational reports, and the financial accounts.

With GIZ support, the State Chief Accountant (Receveur Général des Finances) issued a memorandum (2163/DGTCP/RGF/SCL/SP) in June 2013 stipulating that WMONEY was now the only recognised local government accounting system. A GIZ official noted:

This meant that besides the 25 local governments that GIZ supports, the programme has been deployed in the remaining 52 local governments.

A 2015 TAD report revealed 'budget execution reports, procurement contract reports, surplus and deficit accounts, [and] a balance sheet' had been added. Stakeholders reacted positively:

WMONEY is a revolution. ...In 2014, 76 local governments out of 77 produced their accounts the only one which did not... had an administrative problem ...In the past, only ten managed to produce accounts. ...[All] struggled days and nights for three, four months. WMONEY came in and they now do it within a day! [Now] ...they have more time to deal with other matters. Previously they complained about lack of personnel and other resources ...The programme [satisfies] .... a major requirement of donors who often complained they fund local governments but never got any accounts of how they spend the money [TAD official].

It was an event! The first time since decentralisation that almost all local governments produced the Compte de Gestion [Senior TAD official].

If the local government accountant keeps their accounting records up-to-date and regularly enters the transactions as they occur, they should be able to produce the financial accounts at the financial year-end ...this is a major reform....You should produce the financial accounts without the help of anyone. That's an innovation! [User].

WMONEY is a positive experience. ... People are proud of what they got... [WMONEY] facilitates the centralisation of data: instead of long data collection missions across local governments [TAD] now get this data easily ... financial accounts are produced in all the local governments ...They appreciated our approach. In terms of ownership ...the experience is a success ...compared with other experiences. [GIZ official].

A senior TAD official recalled how the development team now regularly visit users of WMONEY:

A team composed of the IT people who designed and developed the programme, officials of local governments and from the TAD was set up to monitor all the local public accountants ... So twice a year they visited every local government to monitor the use of the programme and deal with any issues or difficulties experienced... The IT people also helped correct any errors in the accounting treatment of transactions not initially foreseen.

To limit human errors and improve the financial information's reliability, an interface was initiated between WMONEY and the budget management programmes - GBCO and LGBC, also GIZ funded - at mayor's offices. A senior TAD Official recounted how now:

once a payment order is issued by the Mayor's office it is transmitted electronically to WMONEY ...there is no further manual entry regarding the order. The local government's budget is also imported and integrated in WMONEY with eventual modification at the year-end: e.g. budget amendments.

A development team member made similar observations:

WMONEY and the budgetary programmes (GBCO and LGBC) exchange electronic data. We developed an interface to enable these exchanges. The Mayor's office sends the data electronically ... to WMONEY at the local public accountant's office. WMONEY knows how 
to receive the data ...[and] it deals with both revenue and expenditure... We met with those who designed GBCO and LGBC and defined what to do from each side. Only work from their side [the consultant] was billed, we didn't bill GIZ anything.

WMONEY accommodated local conditions, unlike ASTER. A development team member explained:

A server is needed for ASTER and an established network and individual workstations...But the ...network ... is a major challenge ... However, for WMONEY a single workstation suffices; and if the volume of data increases significantly an appropriate network may be considered to increase the workstations required, but this is not necessary presently. ...With ASTER, the database is ORACLE which is heavy (and difficult to manipulate) ... and licence costs etc. are expensive... so the operating cost is very high. WMONEY is developed with less expensive tools - the cost is insignificant ...[It] is very simple which facilitates its adaptation as users' needs evolve. ...ASTER is very complex and ...not made for an environment like ours; we cannot modify its parameters easily to respond to users' needs. We depend on those who hold the sources and are responsible for maintaining it.

Infrastructure networks, including the internet, are problematic in Africa and Benin. Insufficient power is the largest constraint and cause of failure for infrastructure projects, including IT ones (Commonwealth Business Council, 2013; WB, 2010). WMONEY accommodated these deficiencies, whereas ASTER, despite over a decade of implementation, did not and in 2015 it remained incomplete. The development team claimed WMONEY cost less than US\$30,000, whereas ASTER has cost over US\$12 million ${ }^{11}$. Stakeholders recognised that WMONEY is simple, flexible and easily adaptable to evolving user needs. The team who worked on both WMONEY and ASTER commented that ASTER's lack of such attributes caused major implementation problems. A team member commented:

We are managing something [ASTER] which doesn't exist. We are doing our best to maintain it so they don't blame [us]. ... unfortunately, we must manage these contradictions.

\subsection{Donors: pragmatism and conditions}

GIZ and the development team initially wished to address all government accounting but senior civil servants refused to extend it to central government accounting. A senior TAD official commented: 'it is not in the interest of certain people that you bring in more accounting'. The issue was politically sensitive. A TAD official explained:

It was France who brought ASTER and required us to hold onto it. So they [officials] no longer wanted to hear anything about WMONEY in central government accounting ...It's that pressure that made officials [at TAD] to put themselves behind ASTER unconditionally.

A development team member recalled:

When we got this opportunity [to develop WMONEY], we said to officials: 'With this programme we can deal with both the central government and local government accounting. It would be easier for local public accountants to use one tool ... The proposal was rejected outright ...we openly received serious threats... They don't want to see us in that area; and we needed to withdraw... It was stated very clearly. I couldn't believe it - I was numb.

Consequently, developers concentrated on local government accounting. Local public accountants complained that no programme dealt with central government accounting but to no avail. For example:

${ }^{11}$ This could not be corroborated from accounting records or other documents as access was denied. 
We are public accountants with two hats: principal accountants [comptables assignataires] for local governments, and accountant representatives [comptables mandataires] for the State Chief Accountant ... So we maintain simultaneously local and central government accounting. We need the programme [WMONEY] to keep both but currently it is impossible.

GIZ focussed on 'what can work locally?', and letting indigenous actors, particularly TAD leaders, IT staff, users, and local officials, identify problems and workable solutions. A GIZ official commented: 'Our approach involves coaching, training and professional development; we left the design and development of the application to locals'. However, GIZ realised that political pressure alongside TAD leadership commitment and civil servants' participation was crucial. As a GIZ official inferred: 'When there was an issue that required political intervention, we didn't get involved in politics but we tried to lobby through our network of supporters.' Another GIZ official said:

GIZ provided financial support to [develop WMONEY].... when someone needs to come from outside to make it work, then things will come to a standstill; and the programme would bear within itself the germs of its non-use. So WMONEY is developed $100 \%$ by TAD technicians.

They responded with alacrity, working weekends and during breaks when necessary. A user exclaimed: 'I came to Cotonou ...for an issue with WMONEY and I was given an IT official who helped during his lunch break.' However, GIZ officials recognised this was partly a consequence of conditionalities.

The TAD is monitored from all sides... the work we do with the TAD is facilitated by the EU and the government signed a conditionality agreement to ensure transparency in the management of the financial support provided by donors. ... Without such a conditionality .... and the attention given to TAD activities by the EU... it would be very difficult.

Production of the Comptes de Gestions was a condition for subsequent budgetary support ...by donors including the EU ... Thus, TAD officials pressured civil servants to produce the Comptes de Gestion within the required time to report back to the EU that this conditionality has been achieved. ...WMONEY certainly benefited from this.

When donors paid limited attention, reform could be sluggish, as a GIZ official recounted:

We are also working with the Revenue Department ...There is no EU conditionality and no performance indicators as a condition for budget support. ...The absence ... made the attention given to fiscal decentralisation initiatives and related reforms very weak compared to the TAD.

\subsection{Indigenous leadership, good governance and reform success}

Despite delegating powers to local officials, TAD's leadership was important. They provided material, financial and regulatory support (memorandum 2163/DGTCP/RGF/SCL/SP), and incentives and sanctions to reinforce compliance. For example:

The Head of the TAD provided funding for .... a computer, a printer and an inverter for each local government. [TAD official]

If accountants failed to produce annual accounts on time, TAD's senior officials acted. One explained:

The hierarchy gave all Receveurs a deadline to 30 June 2015 to produce the Compte de Gestion. Those who didn't [had] ... to explain why. There were six local governments concerned and ...five produced the accounts... It means they did not use the programme. If transactions are regularly entered, there is no reason for a delay. Some accountants were even threatened to be removed... Some had to work nights and others had to bring their computers here at the headquarters to seek help from the IT staff. People woke up with the pressure exerted; without pressure they wouldn't. 
By 2016, the deadline to submit the accounts, i.e. the Compte de Gestion, was reduced from 30 June to 30 April:

The TAD Head made it very clear: if a Receveur fails to submit his/her accounts by 30 April he/she will be ... replaced. An administrative note ... shows how seriously the hierarchy takes compliance... As a result, you won't see any accountant [i.e. Receveur] waiting for the deadline before submitting their accounts. They all file their accounts on time! [TAD official]

The system improved local governance. Resource deployments were more traceable and transparent, it reduced corruption by separating duties of personnel, and it strengthened budgetary control and tax collection.

Previously when the Mayor's office issued the payment order, the same office issued the payment slip - avis de crédit and bon de caisse - and attached it to the payment order to the local public accountant: the only thing he did was to sign and pay. Yet the issuance of the payment slip should be his responsibility. WMONEY [does this] ... and separates duties with the Mayor's office [senior TAD official].

The Mayor's office issues 'mandats' [payment orders]. When this gets to WMONEY ... it does budgetary control. There is an amount of spending for each budget line. If it is budgeted to spend [\$]100 on stationery, and the Mayor's office issues a purchase and payment order for $[\$] 15$, WMONEY will check the account. ... Suppose they have used $\$ 90$ out the $\$ 100$ budgeted, the system would reject it [and it] ...will check whether the payment is for a service. If so, taxes need deducting ... and only the net amount paid to the beneficiary. The system ....generates automatically the related accounting entries and payment document - the Bon de Caisse - which testifies payment has taken place [WMONEY presentation document].

Some officials colluded to disguise fraud. TAD officials explained how:

The purchase or procurement contract the payment order is raised for may be a bogus contract; they can put up something fictitious with all the supporting documents. It will go through... be paid and [WMONEY] cannot do anything! ...The Mayor and the administrative accountant is involved. They can involve the local public accountants or decide not to tell him anything. The contract will be paid because it comes with all the supporting documents required by the local public accountants ...If they don't put up fake purchase and procurement contracts, they will inflate the contract price. There is no control system to detect this. That's how they get rich.

Last week, a local public accountant was presented with a payment order related to New Year seasonal celebrations at a local government... [He] knew the event did not take place but he was presented with all the evidence required to justify it occurred. So he couldn't do anything but pay, and [WMONEY] couldn't do anything either.

However, WMONEY created an audit trail, crucial for ex-post control. A senior TAD official explained:

Once a transaction is entered, it is no longer possible to hide or eliminate it.... Transactions and payment orders issued by the Mayor's office must be paid for in WMONEY by the accountant who issues the payment slip ... What WMONEY does for good governance is that it provides traceability of all transactions incurred [which] ... allows audit institutions to access information to examine the supporting evidence/documents ... [and] whether there has been appropriate management of resources.

WMONEY tracked such transactions. Consequently, ex-post audits, especially by the Chamber of Accounts, could hold transgressors to account. For example, an external audit, commissioned under Dutch pressure, revealed the PPEA II scandal ${ }^{12}$ whereby CFA 8 billion

\footnotetext{
${ }^{12}$ See: http://www.lanouvelletribune.info/benin/politique/24870-affaire-ppea-2-yayi-presente-les-excusespubliques-du-benin-aux-pays-bas [Accessed 2 August 2015]
} 
(US\$ 16 million) for water improvements, partly funded by the Netherlands, was misappropriated. The audit report claimed the perpetrators 'set up a number of dummy companies which signed fake procurement contracts ... and then disappeared. ${ }^{13}$ When TAD officials were asked why they paid these invoices, they responded that all the evidence required was provided.

The reforms are proving dynamic - 'WMONEY is continually being expanded' [user] by the development team and users, e.g. to 'Valeurs Inactives' (inactive values) - tickets collecting tax from market traders; stamps in the Mayor's office legalising documents; parking tickets; and procurement contracts.

Previously, inactive values were a major source of misappropriation. Interviewees recounted:

The Accounting Division simply recorded cash receipts related to inactive values, nothing else, so there was no control. [User]

People took the tickets, they went in the various markets, they issued them, and cashed the money; it was uncontrollable! It happened outside the accounting system. [TAD official].

Now the 'Monitoring of Inactive Values Movements' application monitored ticket stocks and sales. A development team member stated that:

The local public accountant can check inactive values anytime; it gives them their cash balance, how much the Mayor's agents have deposited, and the stock of tickets at hand ... The accountant knows exactly whether there is any collection not yet deposited.

Users confirmed this:

When we receive the inactive values from the printing house they are entered in the 'portfolio of inactive value account'. When the Régisseur [Steward at Mayor's office] takes stocks to place on the markets they sign a discharge slip and we debit it to the account 'Approvisionnement des Agents Collecteurs' or 'Correspondants'. You just enter the information and WMONEY knows in which accounts to record the various transactions... Similarly, when the Régisseur deposits cash collected from inactive values ...you integrate them in the system... when the accounts do not balance you know where the difference lies and you act on it.

When an inactive value is entered, WMONEY will indicate the amount the Steward at the Mayor's office has taken ... So when I do my reconciliation I call the Steward and ask them to check the situation at their end... Now when differences occur we investigate them.... When you do this regularly, you are not surprised at the year-end with unjustified differences - you already know where the problems lie.

Inactive values were a source of corruption for many years, so the reform met resistance:

About half the local governments claimed they could not maintain the inactive value account. When you ask them why, they say that they don't know how to use it. ... The application is very simple, they have been trained on it, and all the other governments use it well. [TAD official]

WMONEY was also expanded to monitor externally funded procurement contracts. These were:

a significant portion of local government business... when you need some information on a contract you must look and re-look for the payment order, a register, and this and that [User].

\footnotetext{
${ }^{13}$ See: http://beninwebtv.com/2015/08/benin-scandale-du-ppea-2-les-4-banques-impliquees/ [Accessed 3 August 2015]
} 
Some users had created Excel spreadsheets to monitor these but their capacity was limited. A WMONEY application from the development team became operational from January 2016. Users were trained on how to use it. Two recounted:

We attended a seminar and were presented an application about how to monitor procurement contracts... WMONEY gives ... information regarding related transactions: whether the contractor has paid the withholding deposit; whether work completed has been paid. You have all the information you need on all procurement contracts and the different stages they have gone through.

With WMONEY you can monitor procurement contracts - even when you are removed from your position, your successor can follow up everything.

GIZ's support for accounting emanated from their belief that good governance is essential to development. An official commented:

It would be wrong to leave aside governance issues on the basis that they have no or limited links with poverty reduction. [Otherwise] we will do the same things we did in the 1970s by supporting large infrastructure projects not managed in a sustainable manner.

GIZ's officials claimed WMONEY reduced poverty because citizens and civil society organisations could participate in public hearings about the accounts. A GIZ official stated:

An aim of decentralisation which GIZ supports is to improve service delivery, quality of spending, and citizens' access to basic services... Good management of local governments in terms of finance and accounting contributes to this... We have identified several cases supporting this.... Support for capacity building in budget management, production of accounts and citizens' participation in local governments, for example, has positively influenced clean water and education service provisions. ... When deciding on transfers [now we] ...first ask whether the governments are well managed, whether they have a good accounting system, whether funds are traceable and so on. ... Financial governance contributes to poverty reduction.

Capacity building extended to:

representatives from civil society organisations ... while [GIZ] supports the production of accounts, it also assists the organisation of public hearings on the accounts [which] ...have strengthened transparency in the management of local governments' business (2014 GIZ report).

The report noted how public hearings have become habitual for local officials and users.

\subsection{Neo-patrimonial leadership challenges}

Neo-patrimonialism represents a major challenge for development reforms, not least accounting ones, in Benin (Bierschenk et al., 2003). Without the attention GIZ and the EU paid to the TAD's activities through conditionalities, the reform, albeit its exclusive focus on local governments, would have been difficult or even impossible to implement. Nevertheless, a GIZ Official acknowledged resistance from political leaders beyond the remit of the TAD: 'When decisions over which we have no control come from the top, they can change a lot of things.' More progress would have materialised had reforms not faced neo-patrimonial challenges. For example, the appointment, qualifications, transfers and promotions of accountants remained problematic: many did not meet meritocratic criteria.

Some local public accountants appointed did not really qualify, which made things complicated [TAD official].

Staff transfers and career development are strange; politics gets in and people are rotated as [political] officials wish. So, someone can be trained today and master the system, and the 
following day he is removed and put in a different position somewhere else. And they would send someone who has never heard about the programme. [GIZ Official]

When civil servants wanted to develop WMONEY to address central government accounting needs at municipalities, TAD officials received orders from above stopping this: 'they don't want to see us in that area' [Senior TAD official]. Neo-patrimonialism still inhibits substantive reform and participation.

\section{Conclusions}

GIZ support allowed civil servants to resuscitate WMONEY, abandoned for about a decade, across all local governments. Enquiries to the TAD in March 2017 revealed that local governments now produce their accounts before the deadline of 30 April. New developments for managing donor funded projects and producing financial statistics for economic analysis are being implemented without GIZ's support. Its gradual phasing out of direct involvement from the reforms since 2016 is consistent with GIZ's focus on sustainable development.

WMONEY granted local civil servants and beneficiaries influence over the technology, its design and implementation, and leadership and ownership of the process. This increased their sense of accountability, commitment, and created a cheap but effective system suited to local conditions and laid the basis for greater civil society participation in budgeting. Thus the accounting reform met expectations regarding outcomes (preparation of accounts and their use) and process (local involvement). It is difficult to assess whether a participatory process is worthwhile (Cleaver, 1999; Morris, 2003). However, our case reveals the effectiveness of a participatory approach which combines instrumentalism and empowerment. The findings are consistent with similar fieldwork (Awio and Northcott, 2001) and research advocating greater indigenous participation (Lassou and Hopper, 2016; Mosse, 2004). The results contrast sharply with many other government accounting reforms in Africa where often participatory involvement does not extend beyond central government officials in capital cities.

Senior TAD officials soon recognised they did not fully understand issues on the ground and supported participatory development of WMONEY lower down. Nevertheless, their leadership and commitment were essential as the project required central government co-ordination and support. WMONEY was implemented incrementally to control potential failure costs alongside continual training to develop local accounting capacity. This proved more effective than the wholesale implementation of complex foreign systems (Hopper et al., 2017). Local involvement and training helped sustain the reform when GIZ support ended, unlike many other government accounting reforms in Africa (Diamond and Khemani, 2005) and, through learning by experience, users successfully requested additional functionalities. The exercise reduced local dependence on external technology and central government finance.

However, the EU and GIZ had to judiciously use conditionalities. Benin's government is widely recognised as neo-patrimonial with little appetite for better central government accounting, attested by their substitution of WMONEY by ASTER and its continuation despite its failings (Lassou et al., 2014). Senior civil servants would not address central government accounting for political reasons but they supported local government reforms, where national neo-patrimony's remit was less. Similarly, donor agencies pragmatically limited reform to what was politically feasible, and took advantage of the political space available. The case illustrates how civil servants can foster effective reforms despite a national neo-patrimonial political regime. Nevertheless, neo-patrimonial patronage remained: staffing was problematic - some accountants lacked the necessary skills, and others were promoted despite poor performance 
and limited accounting knowledge. Also, despite WMONEY's success, its further developments remain problematic. A GIZ official commented:

We can leave WMONEY as it is or improve it further, and plan its financing... its interface with the budgetary programmes in the Mayor's office remains a challenge. They need a consultation framework that brings together officials in local administrations; those who developed the programmes; and the accountants... But who will fund it? Who will coordinate it? It needs to be institutionalised... When our supports ends we could lobby other donors to fund it within the government budget but the concern is whether they will use the money to that purpose.

This reinforces the importance of donors' long-lasting presence. Without GIZ's long experience in Benin the local government accounting reforms may never have materialised. Without their aid and support they may have suffered the fate of other failed African accounting reforms.

To conclude, the study adds to the limited knowledge on implementing public sector accounting systems in Africa. Unusually it reports an effective adoption by locals collaborating with Northern aid agencies. Despite neo-patrimonialism, 'space' was created for local agents to act. Given the negative features of neo-patrimonialism, developers had to think and act politically to create feasible and sustainable reforms. Often pragmatism and incrementalism has to over-ride idealism. The aid agency's lasting local involvement was vital, which questions donors' reliance on global accounting firms with fleeting local knowledge. Participatory and incremental approaches were vital. Local civil servants, when empowered and granted ownership under effective central leadership with donor support, have greater capacity to design and implement accounting reforms related to governance than is often recognised.

\section{References}

Ackerman, J. (2004), Co-Governance for Accountability: Beyond "Exit" and "Voice", World Development, 32, 447-463.

African Development Bank (2005), Benin - Country Strategy Paper 2005-2009, African Development Bank (Tunis).

African Development Bank (2012), Benin - Country Strategy Paper 2012-2016, African Development Bank (Tunis).

Akakpo, M.B. (2009), Réflexions sur la Gouvernance Financière au Bénin, Transparency InternationalBénin (Cotonou).

Andrews, M. (2012), The Logical Limits of Best Practice Administrative Solutions in Developing Countries, Public Administration and Development, 32, 137-153.

Andrews. M. (2013), The Limits of Institutional Reform in Development, Cambridge University Press (New York).

Awio, G., S.R. Lawrence and N. Northcott (2007), Community-led initiatives: Reforms for better accountability? Journal of Accounting and Organizational Change, 3, 209-226.

Awio, G., \& Northcott, D. (2001). Decentralization and budgeting: The Uganda Health Sector Experience. International Journal of Public Sector Management, 14 (1), 75-88. Doi: http://dx.doi.org/10.1108/09513550110387093

Bakre, O.M. (2008), Financial reporting as technology that supports and sustains imperial expansion, maintenance and control in the colonial and post-colonial globalisation. Critical Perspectives on Accounting, 19, 487-522. 
Bierschenk, T., and J-P.O. de Sardan (2003), Powers in the Village: Rural Benin between Democratisation and Decentralisation. Africa, 73,145-173.

Bierschenk, T., E. Thioléron and N. Bako-Arifari (2003), Benin. Development Policy Review, 21,161178.

Bland, G. (2011), Supporting Post-conflict Democratic Development? External Promotion of Participatory Budgeting in El Salvador, World Development, 39, 863-873.

Blundo, G. and J-P. Olivier de Sardan (2006), Everyday Corruption and the State. Citizens and public officials in Africa., Zed (London).

Cammack, D. (2007), The Logic of African Neopatrimonialism: What Role for Donors? Development Policy Review, 25, 599-614.

Chang, H-J. (2006), Kicking away the ladder: Development strategy in historical perspective, Anthem Press (London).

Commonwealth Business Council (2013), Africa Infrastructure Investment Report, Commonwealth Business Communications Limited (London).

Crook, R.C., and D. Booth (2011), Conclusion: Rethinking African Governance and Development. Institute for Development Studies Bulletin, 42, 97-101.

Diamond, J. and P. Khemani (2005), Introducing Financial Management Information Systems in Developing Countries, IMF (Washington).

Fjeldstad, O-H. (2003), Fighting Fiscal Corruption: Lessons from the Tanzania Revenue Authority. Public Administration and Development, 23, 165-175.

Fontana, L.B. and J. Grugel (2016), The Politics of Indigenous Participation Through 'Free Prior Informed Consent': Reflections from the Bolivian Case, World Development, 77, 249-261.

Gisselquist R.M. (2008), Democratic Transition and Democratic Survival in Benin, Democratization, $15,789-814$.

Goddard, A., M. Assad, S. Isa, J. Malagila and T.A. Mkasiwa (2015), The 'two publics' and institutional theory - A study of public sector accounting in Tanzania, Critical Perspectives on Accounting, (In press).

Graham, C. and M. Annisette (2012), 'The Role of Transnational Institutions in Framing Accounting in the Global South', In: T. Hopper, M. Tsamenyi, S. Uddin and D. Wickram.asinghe (Eds.), Handbook of Accounting and Development, Edward Elgar Publishing (Cheltenham).

Harrison, G. (2004), The World Bank and Africa: The Construction of Governance States, Routledge (London).

Hedger, E. and P. de Renzio (2010), What do Public Financial Management Assessments Tell Us about PFM Reform?, Overseas Development Institute (London).

Hepworth, N. (2015), Debate: Implementing Advanced Public Financial Management Reform in Developing Countries, Public Money and Management, 35, 251-253.

Hopper, T., M. Tsamenyi, S. Uddin and D. Wickramasinghe (2009), Management Accounting in Less Developed Countries: What We Know and Needs Knowing. Accounting, Auditing and Accountability Journal, 22, 469-514.

Hopper, T., M. Tsamenyi, S. Uddin and D. Wickramasinghe (Eds.) (2012), Handbook of Accounting and Development, Edward Elgar Publishing (Cheltenham). 
Hopper, T., P.J.C. Lassou and T. Soobaroyen (2017), Globalisation, Accounting and Development. Critical Perspectives on Accounting (in press).

Hove, M. and A. Wynne (2010), The experience of medium term expenditure framework \& integrated financial management information system reforms in sub-Saharan Africa: what is the balance sheet? ACBF (Harare).

IMF (2003), Benin: Enhanced Initiative for Heavily Indebted Poor Countries - Completion Point Document, IMF (Washington).

Irvin, R.A. and J. Stansbury (2004), Citizen Participation in Decision Making: Is It Worth the Effort? Public Administration Review, 64,.55-65.

Iyoha, F.O. and D. Oyerinde (2010), Accounting infrastructure and accountability in the management of public expenditure in developing countries: A focus on Nigeria, Critical Perspectives on Accounting, $21,361-373$.

Jeune Afrique. The Africa Report. Jeune Afrique No. 41, June; 2012.

Lassou, P.J.C. and T. Hopper (2016), Government Accounting Reform in an ex-French African Colony: the Political Economy of Neo-colonialism. Critical Perspectives on Accounting, 36, 39-57.

Lassou P.J.C, Tsamenyi, M \& Hopper, T. (2014), Political Economy of Accounting and Governance in Africa. Paper presented at the Critical Perspectives on Accounting Conference, 7-9 July, Toronto.

Lienert, I. and F. Sarraf (2001), Systemic Weaknesses of Budget Management in Anglophone Africa, IMF (Washington).

McLeod, R.H. \& Harun, H. (2014). Public Sector Accounting Reform at Local Government Level in Indonesia. Financial Management and Accountability, 30, 238-258.

Médard, J.F. (1983), La Spécificité des Pouvoirs Africains. Pouvoirs, 25, 5-22.

Mkandawire, T. (2015), Neopatrimonialism and the Political Economy of Economic Performance in Africa: Critical Reflections. World Politics, 67, 563-612.

Moreno, A. (2002), Corruption and Democracy: A Cultural Assessment. Comparative Sociology, 1, 495-507.

Mosse, D. (2004), Is Good Policy Unimplementable? Reflections on the Ethnography of Aid Policy and Practice. Development and Change, 35, 639-671.

Neu D., E.O. Gomez, C. Graham and M. Heincke (2006), "Informing" technologies and the World Bank. Accounting, Organizations and Society, 31, 635-662.

Olowu, B. (1999), Combatting corruption and economic crime in Africa - An evaluation of the Botswana Directorate of Corruption and Economic Crime, International Journal of Public Sector Management, 12, $604-614$.

Romijn, H.A. and M.C.J. Caniëls (2011), Pathways of Technological Change in Developing Countries: Review and New Agenda. Development Policy Review, 29, 359-380.

Rondinelli, D.A. J.R. Nellis (1986), Assessing Decentralization Policies in Developing Countries: The Case for Cautious Optimism. Development Policy Review, 4, 3-23.

Sandbrook, R. J. Oelbaum (1997), Reforming Dysfunctional Institutions Through Democratisation? Reflections on Ghana, The Journal of Modern African Studies, 35, 603-646. 
Schiavo-Campo, S. (2009), Potemkin Villages: "The" Medium-Term Expenditure Framework in Developing Countries. Public Budgeting \& Finance, 29, 1-26.

Speer, J. (2012), Participatory Governance Reform: A Good Strategy for Increasing Government Responsiveness and Improving Public Services? World Development, 40, 2379-2398.

Verschave, F-X. (1998), La Françafrique. Le plus long scandale de la République, Stock (Paris).

Verschave, F-X. (2000), Noir Silence. Qui arrêtera la Françafrique?, Les Arènes (Paris).

Verschave F-X. and L. Beccaria (2001), Noir Procès - Offense A Chefs d'Etat, Les Arènes (Paris).

von Soest, C. (2006), How Does Neopatrimonialism Affect the African State? The Case of Tax

Collection in Zambia, GIGA Working Paper 32.

World Bank (1992), Governance and Development, The World Bank (Washington).

World Bank (1997), World Development Report 1997 - The State in a Changing World, Oxford University Press (New York).

World Bank (2003), World Development Report 2004: making services work for poor people, Oxford University Press (New York).

World Bank (2010), Africa's Infrastructure - A Time for Transformation, World Bank (Washington).

World Bank (2011), Benin: Joint IDA-IMF staff advisory note on the third poverty reduction strategy paper, World Bank (Washington).

World Bank (2013), World development report 2004: risk and opportunity - managing risk for development, World Bank (Washington). 